\title{
Individual, Organizational, and Work Characteristic Affect The Performance of Clinical Supervision in Hospital
}

\author{
Naya Ernawati \\ Master of Nursing, Postgraduate Program, \\ Faculty of Nursing, Universitas Airlangga \\ Surabaya, Indonesia \\ naia_ta@yahoo.co.id
}

\author{
Suharto \\ Tropical Infection Desease Hospital \\ Universitas Airlangga \\ Surabaya, Indonesia
}

Tri Johan Agus Yuswanto

Health Polytechnic

Ministry of Health

Malang, Indonesia

\begin{abstract}
Methods of Clinical Supervision (CS) can improve the quality and completeness of documentation of nursing care. CS has been described according to Proctor's model, which explains the relationship between the supervisor and supervisee in three domains: Normative, formative, and restorative. However, the performance of CS for documentation of nursing care remains underdeveloped in Haji Hospital Surabaya. The aims of this research are to analyse the influence of individual, organisational, and work characteristic factors to the clinical supervision performance in Haji Hospital Surabaya. This study is an explanative research using cross-sectional approach was used. The population In this study are nurses in the eleven wards in Haji Hospital Surabaya and found 55 nurses who selected by purposive sampling. Data were collected using questionnaires and observation. Partial Least Square (PLS) was used to analyse the data. Individual factor (path coefficient $0274, t=2997$ ) play an important role in clinical supervision based on Proctor's model and interpersonal relationship, organisational factor (path coefficient $=0438, t=5320$ ) play an important role in clinical supervision based on Proctor's model and interpersonal relationship. Work characteristic factor (path coefficient $=\mathbf{0 3 6 9}$, $t=4953$ ) play an important role in clinical supervision based on Proctor's model and interpersonal relationship. Factors of the individual, organisational and work characteristic were important to the clinical supervision performance for improving the quality of documentation of nursing care based on Proctor's model and interpersonal relationship.
\end{abstract}

Keywords- Clinical supervision; documentation of nursing care; Haji Hospital Surabaya

\section{INTRODUCTION}

Documentation of nursing is very important because the documentation is evidence of nurses to patients already taking action. Completeness of nursing documentation reflected the quality of nursing care in the hospital. Documentation is an important professional and medico legal requirement of nursing practice in the hospital [1].

Nursing documentation affects the quality of nursing practice, so the need to pay attention and maintain the quality and accuracy of nursing documentation [2], control of nursing documentation is the presence of clinical supervision activities. Methods of clinical supervision can improve the completeness and quality of the documentation of nursing care. CS has been described according to Proctor's model [3].

The clinical supervision performance of the most adopted model of CS according to Proctors model. Proctors model promotion of standards operational procedures. CS has been described according to Proctor's model and interpersonal relationship, which explains the relationship between the supervisor and supervisee. Proctor Model becomes models of CS are most popular in nursing practice has probably become the most adopted because consistent in clinical supervision process and has an international instrument validity (Manchester clinical supervision scale) was developed by [4]. Proctor's model should explain in three main areas, described as restorative, formative, and normative, and explain relationship between the supervisor and supervisees are supported, developed, and guided in their professional identity [5]. It consists of three components: Normative, formative, and restorative [6].

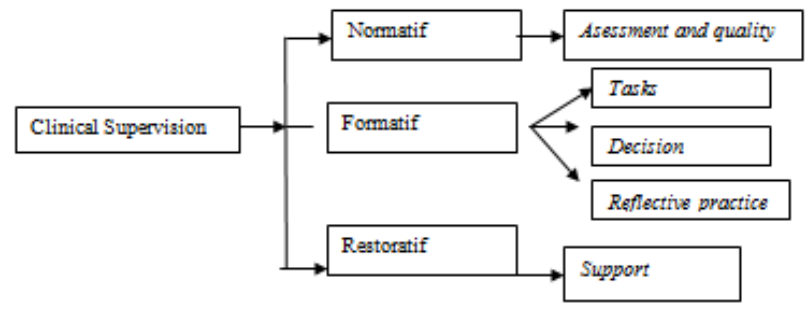

Picture 1. The proctor of Supervision [6] 
Clinical supervision focus on the supervisees need, patient care, and with nurse management, although CS has the potential to contribute to the improved health care. Other the benefits of CS include the development of skills and knowledge, give support, improve the relationship with this staff, reflective practice, reduce conflict, reduce burnout, improve assessment, intervention, and evaluation of clinical supervision process [2].

CS is also a term that is commonly used to define the provision of guidance and feedback to assist in the professional development of an unqualified or trainee health professional who is involved in clinical service provision. Key differences in the definitions provided above are that the former refers to the supervision of qualified professionals to assist in not only the ongoing professional development of clinical skills but also in providing emotional support for nurse [7]. The aims of this research were to analyse the influence of individual, organisational, and work characteristic factors to the clinical supervision performance of documentation of nursing care in Hospital.

\section{METHOD}

The study design was an explanative research utilising the modified from productivity theory from Kopelmen, organisational theory from Robbin and Judge, Manchester Clinical Supervision Scale and interpersonal relationship questionnaire. The respondent of this study contained of nurses associate who work in Haji Hospital Surabaya, in the eleven ward rooms (Pavilion 2, Pavilion 3, Pavilion 4, Marwah 1, Marwah 2, Marwah 3, Marwah 4, Shofa 3, Shofa 4, Al Aqsho 5, and Al Aqsho 4) were obtained from 55 nurses associate selected by purposive sampling. The respondent inclusion criteria included nurses associate who have been work in Haji Hospital Surabaya at more than 2 years, and agree as a respondent in this research.

We hypothesised that there would be a significant effect from individual, organisational, and work characteristic factors to the performance clinical supervision in Haji Hospital Surabaya.

\section{RESULT}

Participants completed the questionnaire that includes three factors (individual, organisational, work characteristic), and perform clinical supervision a self-completion tool that requires for nurses working in Haji Hospital Surabaya to reflect on the usefulness of their CS sessions to fulfil the roles of CS as determined by Proctor's model and interpersonal relationship
TABLE I. CHARACTERISTIC OF RESPONDENT

\begin{tabular}{|c|c|c|c|c|}
\hline No & Respondent & Parameter & $\sum$ & $\%$ \\
\hline \multirow[t]{6}{*}{1} & Age & 20-25 year & 6 & $10.9 \%$ \\
\hline & & 26-30 year & 20 & $36.4 \%$ \\
\hline & & 31-35 year & 18 & $32.7 \%$ \\
\hline & & $36-40$ year & 6 & $10.9 \%$ \\
\hline & & $>40$ year & 5 & $9.1 \%$ \\
\hline & & Total & 55 & $100 \%$ \\
\hline \multirow[t]{3}{*}{2} & Sex & Female & 51 & $92.7 \%$ \\
\hline & & Male & 4 & $7.3 \%$ \\
\hline & & Total & 55 & $100 \%$ \\
\hline \multirow[t]{5}{*}{3} & Work & 5-10 year & 17 & $30.9 \%$ \\
\hline & & 5-10 year & 20 & $36.4 \%$ \\
\hline & & $10-15$ year & 12 & $21.8 \%$ \\
\hline & & $>15$ year & 6 & $10.9 \%$ \\
\hline & & Total & 55 & $100 \%$ \\
\hline \multirow[t]{3}{*}{4} & Education & $\begin{array}{l}\text { Diploma of } \\
\text { nursing }\end{array}$ & 51 & $92.7 \%$ \\
\hline & & $\begin{array}{c}\text { Bachelor of } \\
\text { nursing }\end{array}$ & 4 & $7.3 \%$ \\
\hline & & Total & 55 & $100 \%$ \\
\hline
\end{tabular}

TABLE II. THE DISTRIBUTION OF FACTOR INDIVIDUAL, ORGANIZATIONAL, AND WORK CHARACTERISTIC TO THE CLINICAL SUPERVISION PERFORMANCE

\begin{tabular}{|c|c|c|c|c|c|}
\hline No & Variable & Low & Enough & Good & $\begin{array}{l}\text { Total } \\
(\%)\end{array}$ \\
\hline 1. & $\begin{array}{c}\text { Skill \& } \\
\text { Abilities }\end{array}$ & - & $\begin{array}{c}33(60 \\
\%)\end{array}$ & $\begin{array}{c}22 \\
(40 \%)\end{array}$ & $\begin{array}{c}55 \\
(100 \%)\end{array}$ \\
\hline 2. & $\begin{array}{c}\text { Psychology } \\
\text { cal }\end{array}$ & $\begin{array}{c}9 \\
(16,4 \%)\end{array}$ & $\begin{array}{c}29 \\
(52,7 \%)\end{array}$ & $\begin{array}{c}17 \\
(30,9 \%)\end{array}$ & $\begin{array}{c}55 \\
(100 \%)\end{array}$ \\
\hline 3. & $\begin{array}{l}\text { Reward } \\
\text { system }\end{array}$ & $\begin{array}{c}20 \\
(36,4 \%)\end{array}$ & $\begin{array}{c}27 \\
(49,1 \%)\end{array}$ & $\begin{array}{c}8 \\
(14,5 \%)\end{array}$ & $\begin{array}{c}55 \\
(100 \%)\end{array}$ \\
\hline 4. & $\begin{array}{c}\text { Training \& } \\
\text { Development }\end{array}$ & $\begin{array}{c}9 \\
(16,4 \%)\end{array}$ & $\begin{array}{c}28 \\
(50,9 \%)\end{array}$ & $\begin{array}{c}18 \\
(32,7 \%)\end{array}$ & $\begin{array}{c}55 \\
(100 \%)\end{array}$ \\
\hline 5. & $\begin{array}{l}\text { Leader } \\
\text { ship }\end{array}$ & $\begin{array}{c}17 \\
(30,9 \%)\end{array}$ & $\begin{array}{c}26 \\
(47,3 \%) \\
\end{array}$ & $\begin{array}{c}12 \\
(21,9 \%) \\
\end{array}$ & $\begin{array}{c}55 \\
(100 \%) \\
\end{array}$ \\
\hline 6. & $\begin{array}{c}\text { Organiza } \\
\text { tional } \\
\text { structure }\end{array}$ & $\begin{array}{c}5 \\
(9,1 \%)\end{array}$ & $\begin{array}{c}32 \\
(58,2 \%)\end{array}$ & $\begin{array}{c}18 \\
(32,7 \%)\end{array}$ & $\begin{array}{c}55 \\
(100 \%)\end{array}$ \\
\hline 7. & $\begin{array}{c}\text { Objecti } \\
\text { ves perfor } \\
\text { mance }\end{array}$ & $3(5,5 \%)$ & $33(60 \%)$ & $\begin{array}{c}19 \\
(34,5 \%)\end{array}$ & $\begin{array}{c}55 \\
(100 \%)\end{array}$ \\
\hline 8. & Feedback & $\begin{array}{c}9 \\
(16,4 \%)\end{array}$ & $\begin{array}{c}31 \\
(56,4 \%)\end{array}$ & $\begin{array}{c}15 \\
(27,3 \%)\end{array}$ & $\begin{array}{c}55 \\
(100 \%)\end{array}$ \\
\hline 9 & Normative & $\begin{array}{c}7 \\
(12,7 \%)\end{array}$ & $\begin{array}{c}36 \\
(65,5 \%)\end{array}$ & $\begin{array}{c}12 \\
(21,9 \%)\end{array}$ & $\begin{array}{c}55 \\
(100 \%)\end{array}$ \\
\hline 10. & Formative & $3(5,5 \%)$ & $\begin{array}{c}30 \\
(54,5 \%)\end{array}$ & $\begin{array}{c}22(40 \\
\%)\end{array}$ & $\begin{array}{c}55 \\
(100 \%)\end{array}$ \\
\hline 11. & Restorative & $\begin{array}{c}12 \\
(21,8 \%)\end{array}$ & $\begin{array}{c}32 \\
(58,2 \%)\end{array}$ & $\begin{array}{c}11 \\
(20 \%)\end{array}$ & $\begin{array}{c}55 \\
(100 \%)\end{array}$ \\
\hline
\end{tabular}


TABLE III. THE HYPOTHESIS OUTPUT FROM INDIVIDUAL, ORGANIZATIOANL AND WORK CHARACTERISTIC FACTORS TO PERFORMANCE CLINICAL SUPERVISION TABLE STYLES

\begin{tabular}{cccccc}
\hline No & Variable & $\begin{array}{c}\text { Path } \\
\text { Coefisien }\end{array}$ & $\begin{array}{c}\text { S. } \\
\text { deviation }\end{array}$ & $\begin{array}{c}\text { T } \\
\text { Statis } \\
\text { tic }\end{array}$ & $\begin{array}{c}\text { Inter } \\
\text { pretation }\end{array}$ \\
\hline 1. & $\begin{array}{c}\text { Individual } \\
\text { factors }\end{array}$ & 0.274 & 0.091 & 2.997 & Valid \\
\hline 2. & $\begin{array}{c}\text { Organizatio } \\
\text { nal factors }\end{array}$ & 0.438 & 0.082 & 5.320 & Valid \\
\hline 3. & $\begin{array}{c}\text { Work } \\
\text { Characterist } \\
\text { ic factors }\end{array}$ & 0.369 & 0.075 & 4.953 & Valid \\
\hline
\end{tabular}

Based on the result the respondent demography most of the participant age 26-30 years $(20 \%)$, sex female $(92,7 \%)$, work experience (5-10) years (36.4\%), and diploma of nursing $(92.7 \%)$.

Based on the result all variable (individual, organisational, and work characteristic) from supervisees perspectives have positive correlation with performance clinical supervision $\mathrm{t}>1$.96. Individual factors (path coefficient 0274, $\mathrm{t}=2.997$ ) play an important role in clinical supervision based on Proctor's model and interpersonal relationship, organisational factor (path coefficient $=0438, \mathrm{t}=5320$ ) play an important role in clinical supervision based on Proctor's model and interpersonal relationship. Work characteristic factor (path coefficient $=0369, \mathrm{t}=4953$ ) play an important role in clinical supervision based on Proctor's model and interpersonal relationship. Three factors (individual, organisational, and work characteristic) have significant effect on the clinical supervision performance of documentation of nursing care in Haji Hospital Surabaya.

\section{DISCUSSION}

The research provided insight into describing the factors that influence CS and experience of the nurse perceptions about the performance of clinical supervision especially for documentation of nursing care. Overall there was broad support for CS regarding its perceived value and importance to clinical practice. However, there was a variable understanding of $\mathrm{CS}$ and the distinction between factors individual, organisational, and work characteristic. Clinical supervision sessions were reported as being an important part of the clinical supervisor's work and were perceived as impacting positively to increase the relationship between supervisor supervises, increase the quality of documentation of nursing care, skill and knowledge supervisee's and increase the quality of nursing care.

Individual factors consist from sub variable ability and skills is a major factor affecting the main factors that influence individual behaviour (Gibson, 1997). Ability and skills of nurses regarding documentation of nursing care adjust with the standard operational procedure (SOP) that hospital owned, so nursing management which serves to implementation supervision of nursing actions. It aims to improve the capacity and skills of nurses in the documentation of nursing care. Besides the role of the nursing committee consisting of sub-committees of ethics, quality of nursing and credentialing important role in improving the capabilities and skills of nurses.

Sub variable Psychological which includes perception, motivation, attitude and willingness to learn. Perception in this case related to the nurse assessment of the implementation of nursing care documentation. The motivation of nurses to the documentation of nursing care are requiring from leadership motivation that makes more advanced work. The attitude and willingness to learn make nurses more responsibility for the actions care. Nurses motivation in performing an action will affect the professional work so influential in the quality of service care [8].

Organisational structure is how job tasks are formally divided, grouped, and coordinated [9]. The organisational structure shows communication and relationships of authority and decision-making [10]. One of the functions of management is to lead the delegation, supervision, coordination, and control of the implementation plan of the organisation (Swanburg, 2000). The focus is to guide and improve the motivation with the efforts made to create a reward system, giving positive feedback, integrating the goals of the organisation with staff/individual, reduce job dissatisfaction, supporting resources (human resources, supplies and equipment, training programs, etc).

Training and development in Haji Hospital Surabaya were regular schedule in particular nurses increased knowledge about a variety of information in the form of in-house training involving the expert of experts according to the field or socialisation by peers who have been carrying out training of ex-house training. To maintain organizational commitment there were several attempts (Jackson and Mulyadi, 2001): (1) socialization transparent process recruitment where outline worker and the job description is presented clearly,(2) repair the employee selection process, with a good selection process and accept employment that would not amount to disciplinary problems and low performance, (3) planning orientation programs for good working (4) compensation system and rewards are adequate, fair and competitive (5) career planning and promotions good (6) construction personnel mindset (7) the implementation of the process of internalization vision and core values organization believe (8) work impact.

The leadership style is a way of influencing the behaviour of his subordinate leaders to cooperate and work productively to achieve the goals of the organisation (Malays, 2000). According to Gibson's theory (1987) in Ilyas (2002) explain that a job description or job design is one of the variables that give effect to the behaviour of organisations and individual performance. Design work is a managerial decision and action are the depth, scope and objective of the employment relationship to meet the needs of organisations as well as social and individual needs of the job holder.

Robbin (2008) explains that the feedback is the extent of employees received information that reveals how well they are performing work. Work characteristic showed the higher complexity that increasingly challenging and increasingly powerful determining, boost growth and job satisfaction and increase the effectiveness of work. 
Proctor's model as a framework to review the understanding of $\mathrm{CS}$, three functions (normative, formative and restorative) of Proctor's model. The normative function was addressed by the use of words such as 'expectations', and 'standards' and the formative function was evidenced by keywords such as 'skill development' and 'reflective practice'. The restorative function was addressed by words such as 'support', although the supportive function was commented on to a lesser extent by participants. Based on the persistent and unequivocal reporting of value, clinical supervision should be introduced within general nursing (Butterworth et al, 2008).

\section{CONCLUSION}

This research report any influence detected from (individual, organisational, work characteristic) to the clinical supervision performance for improving quality of documentation of nursing care based on Proctors model and interpersonal relationship. It will seek to deliver enhance recommendation for nurse management in Haji Hospital Surabaya. This research explains that clinical supervision process more important than the output from clinical supervision. So improve the quality relationship between the supervisor and supervisee are very important in the clinical supervision process. The current Nurse management in Haji Hospital Surabaya action plan has already committed to the promotion of clinical supervision based on proctors models and interpersonal relationship for improving quality documentation of nursing care. Furthermore, continuous supervision also important to ensure consistent reporting activities on documentation of nursing care and continuous improvement on the quality service care of the patients.

\section{References}

[1] Nursalam, Proses \& Dokumentasi Keperawatan: Konsep \& Praktik. Jakarta: Salemba Medika, 2008.
[2] J. Brunero, Scott; Stein-Parbury, "The Effectiveness of Clinical Supervision in Nursing: An Evidenced Based Literature Review," Aust. J. Adv. Nurs., vol. 25, no. 3, 2008.

[3] N. Wang, D. Hailey, and P. Yu, "Quality of nursing documentation and approaches to its evaluation: a mixed-method systematic review," J. Adv. Nurs., vol. 67, no. 9, pp. 1858-1875, Sep. 2011.

[4] E. White and J. Winstanley, "A randomised controlled trial of clinical supervision: selected findings from a novel Australian attempt to establish the evidence base for causal relationships with quality of care and patient outcomes, as an informed contribution to mental health nursing practice development," J. Res. Nurs., vol. 15, no. 2, pp. 151-167, Mar. 2010.

[5] Winstanley J, "Manchester Clinical Supervision Scale," J. Nurs. Standar, vol. 14, pp. 31-32, 2000.

[6] S. Lynch L, Happell B, Clinical Supervision for Nurses. UK: Wiley-Blackwell, 2008.

[7] S. Kilminster, D. Cottrell, J. Grant, and B. Jolly, "AMEE Guide No . 27: Effective educational and clinical supervision,” vol. 29, pp. 2-19, 2007.

[8] M. A. Ebright, Patricia R; Kooken, Wendy S Carter; Moody, Roseanne C; Ishaq, "Annual Review of Nursing Education, Volume 4, 2006: Innovations in ... - Marilyn H. Oermann, PhD, RN, FAAN - Google Buku," New York: Springer Publishing Company, 2006.

[9] Robbins, Perilaku Organisasi. Jakarta: Gramedia Grup, 2006.

[10] Marquis \& Huston, Kepemimpinan Dan Manajemen Keperawatan, Teori \& Aplikasi, 4th ed. Jakarta: EGC, 2010 . 